\title{
Developing a Framework for Ranking State and Municipal Governments on Fiscal Sustainability
}

\author{
Davina Kaldani ${ }^{1}$, Autumn Carter $^{1}$, Dr. Eva Kaye-Zwiebel ${ }^{1}$, Jhanvi Aroskar ${ }^{1}$, \\ Kimberly Ang ${ }^{1}$, Madhusudan Ravi ${ }^{1}$, Jinhui Liu
}

\begin{abstract}
:
Fiscally distressed governments tend to draw public attention only amid prominent events like bankruptcy filings, credit downgrades, and serious service cuts. Ideally, before the situation became so severe, the public would be able to quickly assess a government's financial health, both individually and relative to peers. Recognizing the challenge of consistently assessing governments' fiscal health, we developed a uniquely broad data set and proxy measures of fiscal health. For more than 10,000 state and municipal governments in the United States, we extracted comparable data points from audited annual financial reports (FY 2008-09 to 2013-14). We then calculated a budget balance ratio, an asset flexibility ratio, and a pension funding ratio, which we used to rank governments' relative performance. Previous work largely focused on state- and country-level comparisons of fiscal condition using limited samples due to restricted data availability and great variability in accuracy, particularly at the municipal level. These limitations restricted comparability across governments over time and geography. However, we successfully compiled a broad, multiyear public finance database that makes comparisons across thousands of American cities, counties, and state governments possible. Furthermore, our high-level framework of analysis illustrates a way to create simple, broadly applicable measures of municipal financial health.
\end{abstract}

Keywords: government fiscal condition, fiscal solvency, financial ratios, fiscal sustainability, budget balance, asset flexibility, pension funding, public finance, municipal finance

JEL Classification: J18, H70, H80

\section{Introduction}

Across the U.S. and world, government failures or extreme measures taken in the midst of severe fiscal distress have captured the public's collective attention. Unfortunately, that attention emerged only once the distress had manifested itself as government shutdowns, credit downgrades, austerity measures, and significant tax hikes. Ideally, the public, including citizens, researchers, and government officials would be able to access relevant financial data and straight-forward, meaningful assessments of how their governments perform financially before governments experience such severe circumstances. However, often significant limitations to developing these assessments exist: limited access to data often contained in physical or PDF files, limited data comparability across governments' records, and complicated models based on numerous indicators, among others. Consequently, the public lacks such a transparent system whose fundamental measures can apply across a broad array of governments.

To address this, we collected and compiled more than 97,000 government financial reports and 69,000 budgets, extracting "bottom-line" financial figures from the financial 
reports programmatically and manually. By extracting data from financial report PDFs and making both the data and source documents freely available for download on an open-source platform (GovRank.org), we directly improved the limited availability of electronic financial data. Compiling and leveraging the financial reports substantially extends data comparability because the reports are now aggregated in one place and largely adhere to generally accepted accounting principles (GAAP) as defined by the Government Accounting Standards Board (GASB), which establishes reporting standards to ensure basic comparability across governments.

Below, we review, define, and present a framework for ranking state and local governments on fiscal sustainability using our collected data. We present a set of ratios that can be easily understood by individuals with or without backgrounds in governmental accounting. The ratios are budget balance, asset flexibility, and public employee pension funding. Using these, we developed a relative ranking system that, while limited like all others, enables quick assessment of state and local governments' fiscal condition. The terms fiscal sustainability, financial sustainability, and financial condition are used interchangeably throughout this paper.

\section{Literature Review}

Multiple terms such as fiscal health, financial condition, and fiscal sustainability are used to describe the financial circumstances of a government. In some cases, both within academia and practice-oriented research, these terms are used interchangeably (Arnett 2012; Hendrick 2004). In fact, they are defined in numerous ways across different studies. Researchers developed their own definitions or modified previous ones, using various ratios and indicators as they saw fit for their particular research focus. As a result, there is little agreement as to what indicators are relevant when examining the financial condition of a government to determine whether it is fiscally healthy and sustainable or not. Unfortunately, "there is no Yahoo! Finance" for government data (Frank and Gianakis (2010) cited in Kioko (2013)). However, for the purpose of clarification, a fiscally sustainable government is defined here as one that can meet the service needs of its current population without jeopardizing its ability to meet those of its future population. Otherwise, the government is said to be fiscally stressed or unsustainable. A government is deemed relatively more likely to meet the service needs of its current and future populations if it maintains a relatively balanced budget, flexible assets with which to satisfy liabilities, and a relatively low per-capita unfunded pension liability.

One of the most widely used models of financial condition is the International City/County Management Association (ICMA). The ICMA developed the Financial Trend Monitoring System for local government using forty financial and environmental ratios. Their method is similar to how bond rating agencies measure financial condition but too complex to convey to individuals without a background in governmental accounting (Honadle, Costa, \& Cigler 2004; Rivenbark, Roenigk, \& Allison 2010; Kioko 2013).

Others, such as Kenneth Brown's (1993) ten-point test, attempted to simplify the measurement of local government fiscal sustainability. This method is effective and 
simple to communicate but was designed only for government funds (Rivenbark, Roenigk, \& Allison 2010; Maher \& Nollenberger 2009). Kloha et al (2005) built upon Brown's test by taking more factors, such as population growth, into account (Maher \& Deller 2011). Further, Mead (2006) updated Brown's test by incorporating information from government-wide financial statements. Rivenbark, Roenigk, and Allison (2010) also developed a framework based on fund and governmental-wide statements using the most widely used financial indicators to assess local governments' financial condition. They argued that individual funds must be included in the framework as "the majority of policy decisions in local governments are made on a fund-by-fund basis" (Rivenbark, Roenigk, \& Allison 2010).

At the state level, Wang, Dennis, and Tu (2007) developed multiple indicators with equal weight for one year, while Kamnikar, Kamnikar and Deal (2006) developed a framework using three ratios for liquidity, leverage and service level for multiple years (Rivenbark, Roenigk, \& Allison 2010). Arnett (2014) modified the model developed by Wang, Dennis, and Tu (2007) by updating its data to 2012 and adding different weights (Arnett 2014).

As noted above, there are multiple ways to define and develop a framework for assessing a state or local government's fiscal sustainability. These measures are neither exhaustive nor widely applicable to all government levels. Hence, our objective is to develop a framework using multiple indicators with greater emphasis on simplicity and applicability across numerous jurisdictions.

\section{Sample Size}

Included in an initial methods paper following the release of the GovRank.org platform, the following details how we defined and developed the sample of governments we studied:

For the sake of completeness, we naturally included all 50 states on our platform, as well as Puerto Rico. However, the process of deciding which local governments to include was less straightforward. To generate a list of possible cities and counties (and their equivalents), we first identified all incorporated and Census-designated places, along with counties (and county equivalents), as determined by the U.S. Census Bureau. We excluded places that are unincorporated under their state's' laws, thus omitting CensusDesignated Places, "comunidades," and "zonas urbanas" from the platform. We included cities, towns, villages, boroughs, unified governments, and counties, which we collectively describe as "local governments." As of the 2010 Census, which was our benchmark, there were 22,638 local governments.

We then sought to identify those local governments from which we were most likely to successfully obtain financial records, either because they already provided the documents online or because we could request the records without an undue cost burden. We hypothesized that the smaller the population, the less likely we were to be able to obtain the records online or by request. We considered a random sample of 1,000 local governments and determined whether each had a publicly accessible website, phone number, and/ or email address. Overall, $76 \%$ of the surveyed governments had at least a 
website, phone number, or email address. Only 63\% had at least two of these, and only $50 \%$ had all three.

The survey confirmed our hypothesis that government accessibility is highly correlated with population size. We scored each government's level of accessibility on a binary basis: If we located at least two of the three forms of contact or access, it scored a " 1 ," otherwise a " 0 ." Our model showed that if a government had 709 residents or more, it was most likely to score a " 1 ". There were 14,919 local governments that met this population threshold, and they constituted our target local governments from which we sought financial records.

...We group local governments into two groups. Counties are the first group, and all remaining local governments (such as villages, towns, boroughs, unified governments, metro governments, and others) are labeled as "cities". Louisiana parishes and Alaska boroughs are treated as counties. Governments that are both cities and counties are treated as cities. Puerto Rico is classified among the 50 states but its data is not compared to that of the states. (USCS 2016)

\section{Data}

Included in an initial methods paper following the release of the GovRank.org platform, the following details the data sources and data points we leveraged:

[We] successfully collected annual financial reports (mostly audited, though some selfreported) for more than 13,000 local governments with a population of 709 or more, as well as all 50 states and Puerto Rico. Our focal period was fiscal years 2008-09 to 201314. Our initial review of local government websites, and subsequent communications with governments, revealed that fiscal year 2008-09 was commonly the earliest date for which records were available online or by request. Many governments began keeping electronic records from fiscal year 2008-09, often opting not to digitize earlier records at that time. In addition, many states require or recommend that governments retain records on file for only five to seven years before destroying them. [(CORE 2015)] Such standards do not eliminate the possibility of finding earlier records elsewhere, but they substantially increase acquisition costs. Fiscal year 2013-14 was our ending year because the release of annual financial reports typically lags due to the audit process. As a result, 2014-15 reports were not available during the early months of 2015 when we were requesting documents.

In some cases, we obtained more than the six fiscal years' worth of documents we targeted; in others, we obtained fewer. To locate documents, we first searched for existing electronic financial reports and budgets by reviewing the 14,919 individual governments' websites and/or participation in public record repositories. We then downloaded any records we found in our target period, as well as any earlier documents we found. If we did not find all documents for the target period online, we emailed a public record request to the government for the missing years, eventually sending over 10,000 electronic requests. We noted that most governments with a website had already posted some of the documents we sought online, though they were often missing older or more recent records. When we do not have all the documents, it may be because the government could not locate them, the government did not respond to our record 
request, or the fees for fulfilling our request were beyond our budget, meaning they exceeded approximately $\$ 10-20$ per document.

Whenever possible, we obtained comprehensive annual financial reports (CAFRs). These are audited annual financial reports that follow a detailed, semi-structured format and comply with generally accepted accounting principles, as defined by the Governmental Accounting Standards Board (GASB). A minority of governments report their finances in other formats, and in those cases we sought their "non-CAFR" annual reports. These annual financials vary greatly: At one end of the spectrum, they are simplified and/or unaudited reports; at the other, they are audited reports that use the same structure as CAFRs but present the financials on a nonaccrual basis. The entire spectrum deviates enough from a CAFR's structure that we cannot compare governments that produce them to those that produce non-CAFR financials. (USCS 2016)

\section{Implementing the Framework for Ranking}

The process of selecting financial indicators for our framework was initially challenging, as we attempted to reconcile and select indicators from among those various financial ratios used in previous studies. Ultimately, we used a limited number of ratios in our financial sustainability analysis. When the number of ratios increases, the framework becomes more complex, and consequently, more challenging to communicate to a broad audience. We valued the balance between the measures being both meaningful and straight-forward. Furthermore, to ensure broad applicability across governments, we required indicators that were themselves applicable across governments, meaning the data points used in selected indicators needed to be broadly available within CAFRs. However, we acknowledge that, as with all research initiatives in this area, indicator selection is somewhat subjective (Rivenbark, Roenigk, \& Allison 2010). Below, we provide the three ratios we used and examples of each type of jurisdiction and how they performed according to that ratio using the most recent dataset of March 25, 2016.

\section{a. Budget Balance}

Budget balance is the ratio of a government's total revenues to its total expenses in any given year. This ratio indicates whether a government operated in surplus, balance, or deficit in a given fiscal year and on average over time.

\section{Budget Balance $=$ Total Revenues $/$ Total Expenses}

Total revenues include all the income a government generated in a fiscal year, typically including tax collections, fees and charges for services, transfers from other governments, and other revenue sources. Total expenses include all costs a government incurred in a year, typically including costs for general operations, personnel, infrastructure spending, and services that may include corrections, education, healthcare, etc. ${ }^{1}$

1 As reported in the CAFRs. 
We calculated the budget balance ratios for six fiscal years from 2008-09 to 2013-14, requiring a minimum three years' worth of data to calculate the average budget balance ratio. A budget balance ratio greater than 1 indicates the government operated in surplus; equal to 1 indicates the government broke even; and less than 1, operated in deficit. To illustrate, Table 1 includes results for the three best- and worst-performing counties (among the 50 most populous) according to their budget balance ratios. Cuyahoga had an average ratio of 1.25 , meaning it had an average $25 \%$ surplus, while Cook had an average ratio of 0.82 (average 18\% deficit) during the period.

Table 1. Top and Bottom Performing Counties by Budget Balance (2009-2014)

\begin{tabular}{|c|c|c|c|c|}
\hline County & $\begin{array}{c}\text { Budget } \\
\text { Balance } \\
\text { Percentile } \\
\text { Rank }\end{array}$ & $\begin{array}{l}\text { Average Budget } \\
\text { Balance Ratio } \\
\text { 2009-2014) }\end{array}$ & $\begin{array}{l}\text { Average Surplus (Deficit) } \\
\text { per Capita (2009-2014, } 2014 \\
\text { Population) }\end{array}$ & $\begin{array}{c}\text { Population - } \\
2014\end{array}$ \\
\hline \multicolumn{5}{|l|}{$\begin{array}{c}3 \text { Best } \\
\text { Performing }\end{array}$} \\
\hline $\begin{array}{c}\text { Cuyahoga Co, } \\
\text { OH }\end{array}$ & 96 & 1.25 & $\$ 53$ & $1,259,828$ \\
\hline $\begin{array}{c}\text { Gwinnett Co, } \\
\text { GA }\end{array}$ & 94 & 1.21 & $\$ 211$ & 877,922 \\
\hline Pima Co, AZ & 77 & 1.11 & $\$ 107$ & $1,004,516$ \\
\hline \multicolumn{5}{|l|}{$\begin{array}{c}3 \text { Worst } \\
\text { Performing }\end{array}$} \\
\hline Cook Co, IL & 1 & 0.82 & $(\$ 122)$ & $5,246,456$ \\
\hline Suffolk Co, NY & 1 & 0.89 & $(\$ 219)$ & $1,502,968$ \\
\hline $\begin{array}{c}\text { Nassau Co, } \\
\text { NY }\end{array}$ & 2 & 0.91 & $(\$ 246)$ & $1,358,627$ \\
\hline
\end{tabular}

\section{b. Asset Flexibility}

Asset flexibility is the ratio of a government's unrestricted net assets to its total liabilities. This ratio indicates a government's (hypothetical) ability to pay off the debt it currently holds with the most flexible resources (assets) it has. Thus, it is a measure of how manageable the government's debt burden is.

\section{Asset Flexibility $=$ Unrestricted Net Assets $/$ Total Liabilities}

Unrestricted net assets are all assets, in cash or otherwise, that have no restrictions on how the government uses them (GASB Part I 2007). They are the most 
flexible accumulated resources. Total liabilities are the total amount a government owes and is required to turn over to other entities, excluding public employee retirement benefit liabilities. ${ }^{2}$

This ratio is largely hypothetical because it would be extremely rare for a government to ever have to pay all of its outstanding liabilities at once. Thus practically, it at no point needs liquid assets available to cover $100 \%$ of its obligation. However, a government that has a relatively small debt burden and/or relatively large pool of liquid unrestricted assets would be less squeezed by its debt obligations over time. Thus, the higher the ratio, the greater its ability to meet its debts with resources it has available.

We calculated the asset flexibility ratios for six fiscal years from 2008-09 to 2013-14, requiring a minimum three years' worth of data to calculate the average asset flexibility ratios. A government with a negative asset flexibility ratio has negative unrestricted net assets, meaning its debt obligations are typically quite high. The larger the negative ratio, the higher the debt and the lower the asset flexibility. To illustrate, Table 2 includes results for the three best- and worst-performing states according to their asset flexibility ratio. Among the 50 states, Alaska, with a ratio of 3.02, had the best performance, while Illinois (-0.71) had the worst. This means Alaska had flexible assets three times greater than its total liabilities, while Illinois will need a portion of its future revenue to meet debt obligations already incurred. Hence, the smaller the ratio, the larger the debt obligation and the lower the asset flexibility.

Table 2. Best- and Worst-Performing States by Asset Flexibility (2009-2014)

\begin{tabular}{|c|c|c|c|}
\hline State & $\begin{array}{c}\text { Asset Flexibility } \\
\text { Percentile Rank }\end{array}$ & $\begin{array}{c}\text { Average Asset Flexibility } \\
\text { Ratio (2009-2014) }\end{array}$ & $\begin{array}{c}\text { Overall Fiscal Sustainability } \\
\text { Percentile Rank }\end{array}$ \\
\hline $\begin{array}{c}\text { 3 Best } \\
\text { Performing }\end{array}$ & & & 68 \\
\hline Alaska & 98 & 3.02 & 68 \\
\hline North Dakota & 96 & 0.9 & 98 \\
\hline Wyoming & 94 & 0.77 & 1 \\
\hline 3 Worst & & & 5 \\
\hline Performing & 1 & -0.71 & 3 \\
\hline New Jersey & 2 & -0.65 & \\
\hline Connecticut & 4 & -0.64 & \\
\hline
\end{tabular}

\section{c. Pension Funding}

The pension funding ratio is the government's public employee pension funding shortfall per resident. This ratio conveys the projected amount of money it owes retired and current employees in pension benefits that it has not set aside in an interest-bearing fund while controlling for the population of the jurisdiction. Therefore, it is a measure of how manageable the pension debt burden is currently and over time.

\footnotetext{
2 Public employee retirement benefit liabilities are reported elsewhere in a CAFR.
} 


\section{Pension Funding $=$ Unfunded Pension Liability $/$ Population}

Pension liability is the total amount a government has already contractually promised to pay retired and active public employees in monthly pension payments throughout their retirement. Unfunded pension liability is the shortfall between the total pension liability, or the amount the government owes, and the estimated value of the assets in the pension fund.

We calculated the pension ratio by dividing the most recent pension liability available from 2010 to 2014 by the U.S. Census Bureau's 2014 population estimate. The higher the unfunded pension liability per capita, the larger the financial burden a government faces, and the less fiscally sustainable it is. Although there is no academic consensus concerning the specific level at which an unfunded pension liability becomes unsustainable, cities with high unfunded pension liabilities are at greater financial risk in the long term. One reason is that governments are legally required to fund public employee pensions adequately over time. Failing to make sufficient annual pension fund contributions can generate exponential growth in the unfunded portion of the liability. When the liability grows too large, governments may compensate by cutting service levels or raising taxes.

To illustrate, Table 3 includes results for the three best- and worst-performing cities (among the 50 most populous) according to their unfunded pension liability per capita. With a mean unfunded liability per capita of $\$ 1,730$, Washington D.C. tops the list with its public employee pensions being overfunded by $\$ 298$ per capita. New York had the worst performance with its pension being underfunded by $\$ 8,801$ per resident.

Table 3. Pension Funding Performance of Populous American Cities

\begin{tabular}{|c|c|c|c|c|c|}
\hline City & $\begin{array}{c}\text { Pension } \\
\text { Funding } \\
\text { Percentile } \\
\text { Rank }\end{array}$ & $\begin{array}{c}\text { Unfunded } \\
\text { Pension } \\
\text { Liability per } \\
\text { Capita }\end{array}$ & $\begin{array}{c}\text { Total Unfunded } \\
\text { Pension } \\
\text { Liability }\end{array}$ & $\begin{array}{c}\text { Overall Fiscal } \\
\text { Sustainability } \\
\text { Percentile Rank }\end{array}$ & $\begin{array}{c}\text { Population } \\
2014\end{array}$ \\
\hline $\begin{array}{c}3 \text { Best } \\
\text { Performing }\end{array}$ & & & & & \\
\hline Washington DC & 99 & $(\$ 298)$ & $(\$ 196,181,000)$ & 38 & 658,893 \\
\hline $\begin{array}{l}\text { Fresno, } \\
\text { California }\end{array}$ & 98 & $(\$ 126)$ & $(\$ 62,338,000)$ & 48 & 494,665 \\
\hline $\begin{array}{l}\text { San Francisco, } \\
\text { California }\end{array}$ & 92 & $(\$ 14)$ & $(\$ 11,381,058)$ & 41 & 805,235 \\
\hline $\begin{array}{l}3 \text { Worst } \\
\text { Performing }\end{array}$ & & & & & \\
\hline $\begin{array}{l}\text { New York, New } \\
\text { York }\end{array}$ & 1 & $\$ 8,801$ & $\$ 71,948,500,992$ & 1 & $8,175,133$ \\
\hline $\begin{array}{l}\text { Chicago, } \\
\text { Illinois }\end{array}$ & 1 & $\$ 6,296$ & $\$ 16,972,407,000$ & 1 & $2,695,598$ \\
\hline $\begin{array}{l}\text { Boston, } \\
\text { Massachusetts }\end{array}$ & 1 & $\$ 5,063$ & $\$ 3,126,710,000$ & 2 & 617,594 \\
\hline
\end{tabular}


Pension information is more difficult to obtain than the data points we employ in the other ratios for a variety of reasons. In some cases, the governments simply do not provide employees with public pensions. ${ }^{3}$ In many others, the governments do provide pension benefits, but have yet to report them in their CAFRs. Under GASB's applicable accounting standards, governments have not been required to report pension liabilities in those financials. We should note GASB Statement No. 68, issued in 2012, requires greater disclosure of pension-related liabilities starting in fiscal year 2014-15.

\section{Overall Score and Ranking}

We calculated the average budget balance, average asset flexibility, and the pension ratios for every jurisdiction. Then, we normalized each of the ratio values $(0$ to 1), and calculated each government's percentile rank among the sample for each measure. We compared governments only to others of the same type and governments are only ranked within a measure if we could calculate a ratio for it.

We previously stated, "A fiscally sustainable government overall would maintain a generally balanced budget balance ratio, a positive and relatively high net asset ratio, and a low per capita unfunded liability associated with retired public employees' pension benefits." (USCS 2016) There are cases in which a government does well in one of the rankings but its overall rank is low. For example, the city of Fresno, California's unfunded pension liability was in the 98 th percentile (among the best-performers). However, its overall fiscal sustainability rank was in the 48 (Table 3 ). This is because Fresno's budget balance and asset flexibility performance were in the relatively low $40^{\text {th }}$ and $8^{\text {th }}$ percentiles, respectively.

Further, this measure of fiscal sustainability, just like all other measures, could not capture all financial data associated with jurisdictions. Moreover, our ranking system may understate improving or declining trends because it considers six-year averages among two of its indicators. Also, because we included only data points from government-wide statements, our method would fail to capture variations in performance by funds within governments.

The following passage, previously published in our initial methods paper, discusses the non-comparability of audited comprehensive annual financial reports (CAFRs) and nonCAFR reports:

3 We used the most recent unfunded liability. Unfunded liabilities change over time, hence, the most recent unfunded liability represents the best estimate of its size. However, in some cases, the most recent estimate is not from 2014. We summed the unfunded liability for up to five pension funds to which the government contributes. Due to GASB Statement No. 68, issued in 2012 that required governments to disclose more about their pension-related liabilities starting in fiscal year 2014-15, pooled pension systems started to report individual municipalities' share of total pension system liability. In cases where either of these system-level reports existed and the government did not report pension liability in its own annual financial report, we used the system's estimation of the municipality's unfunded pension liability for up to five pension systems. Finally, in addition to pensions, most governments have promised other non-pension benefits to their retired employees, known as Other Post-Employment Benefits (OPEBs). OPEB liabilities are less systematically reported than pension liabilities, so we extracted this data point when available and provided them on GovRank.org, but do not include them in our framework. If a government has unfunded OPEB liabilities, its unfunded retirement liabilities is greater than the amount our pension funding ratio indicates. 
Most non-CAFR reports do not provide any of the data points we sought from CAFRs. Given both this limitation and our desire to measure those governments' fiscal health even with a more limited scope, we opted to provide a modified budget balance rank for them. We calculated their budget balance ratio as general fund total revenues/general fund total expenses (rather than total revenues/total expenses, neither of which was available), which allowed for the most comparable measure of operating position across those governments. However, using the general fund figures does not guarantee we captured the cost of operating the entire government, as the general fund is often one of multiple funds, albeit typically the largest. Thus, a budget balance rank for a government that issues a "non-CAFR" financial report is not comparable to the rank of one that issues a CAFR. (USCS 2016)

\section{Limitations and Challenges}

This framework has several limitations. As a relative framework leveraging bottom-line data, it is intended to provide high-level assessment, not an in-depth assessment into individual governments. Also, the overall rank could potentially hide a particular area of weakness shown by an individual indicator. The following excerpt discusses the accessibility challenges and comparability challenges facing government financial analysis research space:

Accessibility - While many governments are increasingly making financial reports available online, many are not, especially those in small towns with few resources or states that do not mandate such disclosure. Secondly, online records are almost exclusively available as PDFs, making the financial data they contain difficult for most people to access. When records are available only in hard copy, it can require payment of printing, postage, or travel costs and a public employee to scan and mail them. All these factors have contributed to the woefully limited amount of comparable information available about government finances in the U.S.

Comparability - Although governments publish a variety of financial documents, only a limited number of documents comprehensively depict how governments actually operated while allowing for clear, comparable assessments across governments. Government budgets, for example, vary substantially across governments, and even within the same government, over time. Changes such as departmental restructuring, renaming, reclassification, and the election or hiring of new leaders and administrators can alter how governments present budget information over time. For similar reasons, comparison of detailed budget line items across governments is difficult. (USCS 2016)

\section{Conclusion}

The disproportionate public focus on the most fiscally distressed governments, and only once they have exhibited the most visible signs of distress, belies the more universal and forward-looking financial indicators of said distress. We do not purport to have developed a model that predicts specific outcomes such as prominent bankruptcy filings, budget crises, defaults, credit downgrades, repeated tax hikes, and serious service cuts. However, in this paper, we have presented a broadly applicable framework that 
assesses relative fiscal sustainability based on fundamental performance indicators budget balance, asset flexibility, and pension underfunding levels.

The basic premise underlying our model is that by routinely failing to balance incoming and outgoing funds, overleveraging debt, and/or failing to meet legally-binding longterm retirement obligations, a government places itself on a track to fiscal unsustainability that forces it to continue such behavior, restrict its service provision, and/or raise taxes on its citizens. In other words, continued upon for too long, those paths constitute an unsustainable cycle.

Our research initiative not only considered over 10,000 local and state governments, but it also made the data and source records freely available at GovRank.org for other researchers to use going forward. While this research utilized a broadly applicable set of bottom-line data, future research may leverage more detailed data housed within CAFRs. Such explorations may reveal informative patterns within revenue, expenditure, liability, asset, retirement benefit, and other categories.

Not an end in itself, the act of measuring fiscal condition is rooted in the universal desire to see governments functioning efficiently and effectively, while securing services and communities for both current and future generations.

\section{References}

Arnett, S. (2012). Fiscal Stress in the United States: An Analysis of Measures and Responses (Doctoral dissertation). Georgia State University, Georgia. http://scholarworks.gsu.edu/cgi/viewcontent.cgi?article=1035\&context=pmap_diss

Arnett, S. (2014). State Fiscal Condition: Ranking the 50 States. Mercatus Center, George Mason University, Virginia. Retrieved from http://mercatus.org/sites/default/files/Arnett_StateFiscalCondition_v1.pdf

Brown, K. (1993). The 10-Point Test of Financial Condition: Toward an Easy-to-use Assessment Tool for Smaller Cities. Governmnet Finance Review. Retrieved from http://lgc.uwex.edu/Finance/Inservices/2011/kenneth\%20brown-Ten-point-test.pdf

The Civic Federation. (2015). Indicators of Financial Condition: A Comparison of the City of Chicago to 12 Other U.S. Cities from FY2009 through FY2013. The Civic Federation. Chicago, IL. Retrieved from https://www.civicfed.org/sites/default/files/REPORT_FinancialIndicatorsFY09-FY13.pdf

European Commission. (2014). European Economy: Identifying fiscal sustainability challenges in the areas of pension, health care and long-term care policies. European Commission. Retrieved from http://ec.europa.eu/economy_finance/publications/occasional_paper/2014/pdf/ocp201_en.pdf

Governmental Accounting Standards Board (GASB). (1987). Concept Statement No. 1 of the Governmental Accounting Standards Board. Objectives of Financial Reporting. Retrieved from http://www.gasb.org/cs/BlobServer?blobkey=id\&blobwhere=1175824062706\&blobheader=appl ication $\% 2$ Fpdf\&blobcol $=$ urldata\&blobtable $=$ MungoBlobs

Governmental Accounting Standards Board (GASB). (2007). Touring the Financial Report, Part I: The Statement of Net Assets. Governmental Accounting Standards Board. Retrieved from http://www.gasb.org/jsp/GASB/GASBContent_C/UsersArticlePage\&cid=1176156736184

Governmental Accounting Standards Board (GASB). (2007). Touring the Financial Report, Part II: The Statement of Activities. Governmental Accounting Standards Board. Retrieved from http://www.gasb.org/cs/ContentServer?c=GASBContent_C\&pagename=GASB $\% 2$ FGASBCont ent_C\%2FUsersArticlePage\&cid=1176156736216

Hendrick, R. (2004). Assessing and Measuring the Fiscal Health of Local Governments Focus on Chicago Suburban Municipalities. Urban Affairs Review, 40(1), 78-114. Retrieved from http://uar.sagepub.com/content/40/1/78.abstract 
Hendrick, R., \& Crosby, A. (2013). Bankruptcy Triggers and their Relation to Fiscal Solvency: An Examination of Local Governments in Illinois. Retrieved from http://cuppa-pa.uic.edu/wpcontent/uploads/2012/08/Hendrick_Crosby-ABFM-2013.pdf

Honadle, B. W., Costa, J. M., \& Cigler, B. A. (2004). Fiscal Health for Local Governments: An Introduction to Concepts, Practical Analysis, and Strategies. San Diego: Elsevier Academic Press.

Kioko, S. N. (2013). Reporting on the Financial Condition of the States: 2002-2010. Journal of Public Budgeting, Accounting \& Financial Management, 25(1), 165-198. Retrieved from http://pracademics.com/attachments/article/865/Luby\%20Symp_Art\%201_Kioko.pdf

Kloha, P., Weissert, C. S., \& Kleine, R. (2005). Developing and Testing a Composite Model to Predict Local Fiscal Distress. Public Administration Review, 65(3), 313-323. Retrieved from http://onlinelibrary.wiley.com/doi/10.1111/j.1540-6210.2005.00456.x/abstract

Local Government Common Records Retention Schedule (CORE). (2015). Office of the Secretary of State. Washington State Archives. Version3.2. Retrieved from https://www.sos.wa.gov/_assets/archives/RecordsManagement/CORE\%203.2.pdf

Maher, C. S., \& Nollenberger, K. (2009). Revisiting Kenneth Brown's 10-Point Test. Retrieved from http://www.gfoa.org/sites/default/files/GFR_OCT_09_61.pdf

Maher, C. S., \& Deller, S. C. (2011). Measuring Municipal Fiscal Condition: Do Objective Measures of Fiscal Health Relate to Subjective Measures? Journal of Public Budgeting, Accounting \& Financial Management, 23(3), 455-478. Retrieved from http://lgc.uwex.edu/Finance/Inservices/2011/Maher_Deller\%20JPBAFM\%202011.pdf

Mead, D. M. (2006). A Manageable System of Economic Condition Analysis for Governments. In Howard Frank (Ed.), Public Financial Management (383-419). Retrieved from https://www.researchgate.net/publication/264761865_A_Manageable_System_of_Economic_Co ndition_Analysis_for_Governments

Rivenbark, W. C., Roenigk, D. J., \& Allison, G. S. (2010). Conceptualizing Financial Condition in Local Government. Journal of Public Budgeting, Accounting \& Financial Management, 22(2), 149-177. Retrieved from http://pracademics.com/attachments/article/796/Art\%201_Rivenbark\%20et\%20al.pdf

Rivenbark, W. C., \& Roenigk, D. J. (2011). Implementation of Financial Condition Analysis in Local Government. Public Administration Quarterly, 35(2), 241-267. Retrieved from http://www.jstor.org/stable/41506755?seq=1\#page_scan_tab_contents

United States Common Sense (USCS). (2016) Govrank.Org's Methodology. United States Common Sense. Mountain View, CA. Retrieved from http://govrank.org/research/researchText/35

Wang, X., Dennis, L., \& Tu, Y. S. (2007). Measuring Financial Condition: A Study of U.S. States. Public Budgeting \& Finance, 27(2), 1-21. Retrieved from http://papers.ssrn.com/sol3/papers.cfm?abstract_id=985696 